\title{
Znikomek
}

\section{wśród innobytów. Przyczynek do anatomii Leśmianowskiej wyobraźni}

Jak wiadomo, światy przedstawione Bolesława Leśmiana zamieszkują prócz ludzi - odmieńców i kalek albo przeciętnych postaci z ludu, przeżywających niezwykłe przygody - także osobliwe stwory nieludzkie, a raczej nie w pełni ludzkie, bo wprawdzie nieco zwierzęce, jednak i w jakimś stopniu człekokształtne. Wyposażone są w szczególną świadomość - zmodyfikowaną jakąś dewiacyjną hipertrofią albo redukcją. Cechy te, które nazwałbym antropomorfizmem alternatywnym, sytuują stworzenia autora Łąki wprawdzie w sąsiedztwie innych ogrodów zoologii fantastycznej, ale jednak pozostają zamknięte w osobnym rezerwacie prywatnych autorskich wyobrażeń. Przyjrzyjmy się najpierw ich sąsiedztwu, by poszukać możliwych źródeł inspiracji dla postaci wykreowanych w Leśmianowskich balladach.

Proponuję tu jednak spojrzenie ahistoryczne, uwzględniające wyobrażenia zarówno wcześniejsze niż twórczość Leśmiana, jak i późniejsze, gdyż chodzi o porównanie potencjałów ludzkiej wyobraźni, a nie genetyczne śledzenie źródeł konkretnych pomysłów, gdyż wszystkie one w różnym stopniu są pochodną jakichś imaginariów mitologii i folkloru. Celem przeglądu będzie zatem wyznaczenie uniwersalnych wektorów uprawiania różnie pojętej teleologicznie fantastyki. Dlatego rozpocznę od zjawisk w kulturze współczesnej, jako nie tylko najbliższych chronologicznie, lecz także powszechnie dostępnych.

Dopiero na szerokim tle, wyznaczającym horyzont wyobraźni, umieszczę wybrane stwory Leśmiana, próbując odnaleźć ich powinowactwa ze

* Uniwersytet Szczeciński, Wydział Filologiczny, Instytut Polonistyki , Kulturoznawstwa i Dziennikarstwa, Zakład Teorii i Antropologii Literatury, e-mail: karapet@wp.pl. 
wspólnotą wyobraźni dawnej i dzisiejszej, a bliżej przyjrzeć się jednemu z nich, który wydaje się bytem skrajnym - zarówno ontologicznie, jak wyobrażeniowo. W zestawieniu z innymi imaginariami świat Leśmiana okaże się w dużym stopniu autonomiczny i przewyższający radykalizmem kreacji zarówno mitologie, jak ich dzisiejsze transformacje w literaturze fantastycznej, popularnej, humorystycznej czy dziecięcej.

\section{W ogrodach fantastyki}

Współczesny przyrost fantastyki (bo z nazwy „rozwój” świadomie rezygnuję, nie dostrzegając w lawinowym przyroście znamion postępu) sprawia, że populacja stworów zrodzonych z wyobraźni rozmnaża się żywiołowo i w sposób niekontrolowany. Przyśpieszenie tego procesu i tempo mutacji, którego nie uzasadnia żadna teoria ewolucji, odbywa się głównie za sprawą kultury masowej, zdominowanej przez powieści Johna Ronalda Reuela Tolkiena, ich adaptacje i parafrazy w całym nurcie fantasy oraz serię filmową Gwiezdne wojny. To świat już ściśle skodyfikowany, którego znajomość jest warunkiem zrozumienia filmowych fabuł i komunikacji z kilkoma już pokoleniami młodzieży na nich wychowanych. Kluczową rolę pośród postaci grają Jedi -

starożytny zakon „wrażliwych na Moc”, czyli istoty, w których organizmach występuje stężenie midichlorianów. Midichloriany są nanoorganizmami występującymi w każdym żywym organizmie i umożliwiającymi mu Odczuwanie Mocy. W Zakonie Jedi wielką uwagę przywiązuje się do umiejętności panowania nad swymi emocjami, ponieważ niektóre z nich prowadzą na ciemną stronę Mocy i do upadku Jedi ${ }^{1}$.

Dalej możemy dowiedzieć się o ich wrogach Sithach, reprezentujących „ciemną stronę Mocy”, z którymi oni walczą dla utrzymania pokoju w Republice Galaktycznej. Jednym z Jedi jest Anakin Skywalker, we wcześniejszym wcieleniu Darth Vader. Metamorfozę psychiczną bohatera zaznacza stereotypowa zmiana wyglądu, bliska schematom moralitetowym i pierwszym westernom, w których biały kapelusz był atrybutem charakteru pozytywnego, czarny - negatywnego: Skywalker jest niebieskookim blondynem, Vader natomiast jest żółtooki i łysy - wbrew tradycji, która z takim typem urody zazwyczaj kontrastuje piwnookiego bruneta. Ta modyfikacja stereotypu zapewne była unikiem kreatorów przed posądzeniem o rasizm. Zauważmy jednak, iż w tej charakterystyce najważniejsze są cechy psychologiczne, służące za dydaktyczne exemplum. Reszta to pseudonaukowa motywacja typowa dla fabuł science fiction, dowolnie powołująca się na prawa biologii i genetyki. Odkrycia naukowe stanowią trop ciekawy dla stworzenia hipotezy świata alternatywnego, ale tu zaniechany, bo w całej serii dominuje przygodowa 
fabuła z prostym etosem walki i kiczowatą batalistyką. Metamorfoza bohatera zbliża go bardziej do bohaterów romantycznych i pochodnych: Mickiewiczowskiego Gustawa-Konrada i Sienkiewiczowskiego Kmicica-Babinicza niż tajemniczych bytów Leśmiana.

Ponieważ w obszarach kultury popularnej daje się zauważyć przede wszystkim banał kopiowania pomysłów dawnych mitologii z naiwną ich modernizacją, poszukajmy przykładów bardziej oryginalnych w literaturze, gdyż te wydają się bliższe imaginacyjnym "odkryciom” autora Napoju cienistego, a taki jest cel tego przeglądu starszych bestiariuszy.

Księga istot zmyślonych Jorge'a Luisa Borgesa² - to bestiarium z 20. stulecia, jak dotąd najpełniejsze, bo retrospektywne, skompilowane z różnych mitologii starożytnych i średniowiecznych oraz kreacji literackich, ale nie powiązanych fabularnie jak w Metamorfozach Owidiusza, lecz ułożonych $\mathrm{w}$ alfabetycznym porządku encyklopedii. Stwory tam opisane mają swoją genezę i dość długą historię - wprawdzie często wielowariantową, jak mity wędrujące po różnych wspólnotach wierzeń - która kończy się zazwyczaj wcieleniem w jakąś aktualną formę przyrody nieożywionej, przeważnie zjawisko meteorologiczne albo gwiazdozbiór. Oczywiście, są dziwne jako nieistniejące realnie, ale trudno uznać, że zagadkowe, gdyż swoim istnieniem nie przynoszą niepokoju tajemnicy - przynajmniej dziś, w rzeczywistości wirtualnej symulakrów, a więc w perspektywie kurczącego się świata rzeczy niemożliwych.

W ogrodzie Borgesa obok zwierząt fantastycznych występuje fauna rzeczywista, ale zniekształcona legendą i przesądem, taka jak pelikan i salamandra. Argentyński pisarz przytacza również wierzenia drwali z Wisconsin i Minnesoty, wedle których istnieją Latające Pstrągi bojące się wody, Głuptak Zębiasty pływający tyłem, by woda nie dostała się do jego ust, Niezdarnik Goździkowaty, wijący gniazda dnem do góry i fruwający tyłem, gdyż nie obchodzi go, dokąd leci, a tylko to, gdzie był3. Zwierzęta podobnie zdeformowane, o narządach zredukowanych lub pomnożonych albo o nietypowym zachowaniu, tworzyli także liczni baśniopisarze i autorzy wierszyków dla dzieci (jak pominięty przez Borgesa Jan Brzechwa w utworze Na wyspach Bergamutach czy Maciej Wojtyszko ${ }^{4}$ ).

W klasyce mitów grecko-rzymskich, indyjskich, celtyckich czy innych przeważają produkty metamorfozy lub krzyżowania. Być może hybrydy to zwierzęta bliskie gatunkom rzeczywistym, lecz jeszcze nie odkrytym, a przyszłe postępy zoologii poszukiwawczej pozbawią je fantastyczności - tak jak niegdyś nietoperza (uważanego dawniej za pół-mysz i pół-ptaka), a w przeszłości znacznie bliższej okapi - przypominające zarówno zebrę jak żyrafę.

2 J.L. Borges, Księga istot zmyślonych, przeł. Z. Chądzyńska, Warszawa 2000.

3 Tamże, s. 55.

4 Maciej Wojtyszko stworzył jedną z ciekawszych galerii fantastycznych postaci, takich jak: Bromba, Pciuch, Fumy, Gżdacz, Fikander, Gluś w swojej książce Bromba i inni (Warszawa 1975) oraz kilku następnych. Systematykę tej fauny można poznać szczegółowo na stronie: htps//pl.wikipedia.org/wiki/Bromba_i_inni\#Postacie (dostęp: 30.11.2017). 
W kompendium Borgesa znajdziemy jednak ponadto stwory, które mogłyby zainspirować Leśmiana - nie ze względu na wygląd, lecz na rys psychologiczno-egzystencjalny. Oto parę z nich.

Odradek - przypomina szpulkę nici w kształcie gwiazdki z podstawką. Nie wiadomo, po co istnieje, jest mały i rozsnuwa nici, zakochuje się jak dziecko, nie jest groźny. Pochodzi z mitologii słowiańskiej lub germańskiej, a pojawia się w bestiariuszu Borgesa jako wypis z dzieł Franza Kafki ${ }^{5}$.

Squonk (Lacrimacorpus dissolvens), żyjący jedynie w Pensylwanii: ,jest raczej oschły, podróżuje przeważnie o zmroku. Eksperci twierdzą, że jest najnieszczęśliwszym ze zwierząt". Nietrudno go wytropić, bo „ciągle płacze i zostawia za sobą ślady łez” [...]. „Pan J. Wentling [...] miał smutne doświadczenie z pewnym squonkiem [...] Pocieszył go i namówił, by wszedł do worka, po czym zabrał do domu, w pewnej chwili worek stał się lekki, a płacz ucichł. Wentling otworzył worek: były w nim tylko łzy i bąbelki".

William T. Cox, Fearsome Creatures of the Lamberwoods, Washington $1910^{6}$.

Łatwo wątek ten skojarzyć z Leśmianowską balladą Dziewczyna i spuentować: „I nic nie było oprócz głosu”, ale motyw Leśmianowski podlega tu eskalacji, bo znika nawet łkanie.

Elfy - jeśli oddalić potoczną o nich wiedzę jako o Tolkienowskiej „rasie” rozpoznawalnej po uszach, a przyjąć, że ich nazwa pochodzi od niemieckiego "Alp", czyli koszmar, to można je wiązać ze średniowiecznymi wierzeniami, według których ugniatają piersi śpiących, powodując senne koszmary ${ }^{7}$. A zatem właśnie elf może być pierwowzorem Leśmianowskiego Dusiołka, mającego wprawdzie rodowód ludowy i słowiański.

Podobnie mógłby Leśmiana zainspirować Kot z Cheshire i koty Kilkenny pochodzące z Alicji w krainie czarów Lewisa Carrolla. Pierwszy kot obdarzony został „zdolnością stopniowego znikania, tak, że w końcu pozostawał już tylko jego uśmiech, bez pyszczka ni zębów. O kotach z Kilkenny mówi się, iż tak się ze sobą biły, że się nawzajem pożarły, pozostawiwszy po sobie tylko ogony"'.

Bestiarium Stanisława Lema ma natomiast charakter nie historyczno-muzealny, lecz futurologiczno-eksperymentalny, toteż jego wkład autorski jest znacznie większy, gdyż pisarz staje się przede wszystkim kreatorem, a nie jak Borges zbieraczem i antologistą przeszukującym dawne mitologie. Nie ustanawia on jednak żadnego kanonu ni zwartego kompendium, a jego zwierzyniec istnieje w stanie rozproszenia; pojedyncze stwory wiodą żywot samotniczy lub stadny w autonomicznych światach przedstawionych różnych utworów, zwłaszcza opowiadań. Niektóre stwory fantastyczne pokazywane są w perspektywie poważnej, stanowiąc element hipotetycznych światów przyszłości lub przyszłego horyzontu wiedzy o już istniejącym Wszechświecie, o istotach

J.L. Borges, Księga istot zmyślonych, s. 141-143.

6 Tamże, s. 189-190.

7 Tamże, s. 47.

8 Tamże, s. 109. 
i zjawiskach z odległych galaktyk, nieznanych obiektach przyrody, które tylko umownie nazywać można przez analogię „florą i fauną kosmiczną".

Lem początkowo był twórcą z kręgu science fiction, ale potem stał się zawziętym krytykiem i parodystą tego nurtu, toteż jego kreacje kosmiczne mają status niejednakowy, zależny od genologicznych zróżnicowań i modalności przedstawień. Można wyodrębnić trzy ich grupy:

1. Formy życia, powoływane serio, które zmuszają do przekroczenia perspektywy antropocentrycznej i rezygnacji z odwołań do podobnych tylko z pozoru form przyrody ziemskiej. To „płucodrzewa” z powieści Eden, mikrocząstki w kształcie litery "Y" zdolne zbudować dowolny obiekt (Niezwyciężony), "myślący” ocean i rodzone przezeń symetriady w Solaris.

2. Elementy groteskowo-parodystyczne, służące za krytykę i karykaturę naiwnych wyobrażeń u seryjnych twórców science fiction w kulturze masowej. W opowiadaniu Ratujmy kosmos (List otwarty Ijlona Tichego z tomu Dzienniki gwiazdowe) pojawia się skierowane do turystów kosmicznych ostrzeżenie przed złośliwością pewnych istot, a zarazem apel ekologa, który alarmuje przed wyginięciem niektórych gatunków. Narrator wymienia stwory działające na zasadzie mimikry:

wężonóg teleskopek, który w miejscach widokowych rozstawia trzy cienkie długie nogi w kształt trójnoga, rozszerzonym tubusem ogona celuje w krajobraz, a jego ślina imituje soczewkę lunety; wędłowce, czajaki połkliwe (drapieżce czyhające na turystów), rzęsula niedołazka, moczyścier przepaśny, woczykij brutalik (udaje on kioski z wodą sodową, hamaki, natryski z kurkami i ręcznikami), mrówka krzesłówka dręczypupa (udająca wiklinowy fotelik)’9.

Pełna lista „odkryć” parazoologicznych Lema (a niektóre z nich wspierają dość nieporadne rysunki autora) byłaby znacznie dłuższa.

3. W podobnej funkcji parodii występuje fauna kosmiczna wyłącznie w enumeracji samych atrakcyjnie poetyckich i zabawnych nazw, bez żadnych opisów anatomicznych czy funkcjonalnych. Nazwy te służą tylko do wskazania innobytów możliwych, a czytelnikowi zupełnie nieznanych. Pćmy, murkwie, graszaki, plukwy, filidrony, zamry, kambuzele, ściśnieta, wytrzopki, rymundy, trzepce wspierają dydaktyczne przesłanie w noweli Jak ocalat świat z tomu Cyberiada. O gryzmakach i gwajdolnicach dowiadujemy się jedynie tego, iż istniały na firmamencie ${ }^{10}$.

Wkład Konstantego Ildefonsa Gałczyńskiego w rozwój zoologii fantastycznej jest niestety wątpliwy, bo wprawdzie oryginalny, lecz jednostronnie groteskowy, ukierunkowany wyłącznie parodystycznie. W traktacie Nieznani mieszkańcy naszych borów (z cyklu Listy z fiołkiem) autor pobieżnie charakteryzuje kilka zwierząt z wyraźnym lekceważeniem precyzji opisu i jego

9 S. Lem, Ratujmy kosmos (List otwarty Ijlona Tichego), [w:] tegoż, Dzienniki gwiazdowe, Warszawa 1971, s. 413-430.

10 Tenże, Jak ocalat świat, [w:] tegoż: Opowiadania wybrane, Kraków 1975, s. 121-125. 
wartości poznawczej, gdyż inwencja skupia się głównie na niespodziankach onomastycznych. Oto wyimki z jego bestiariusza:

\section{„[...] Ciapciuś}

Nikłe, prawie że niewidoczne stworzonko (żyjątko) z gatunku ssaków obłych. Żywi się śmierdzącą padliną. Rozmnaża się w miarę sił. Chłopcy i dziewczęta, nie straszcie ciapciusia swoimi dzikimi rykami, gdy ten ostatni wygrzewa się na słońcu.

Pitwa

Rodzaj Rypały.

\section{Gulbrason}

Ponury, trawożerny ssak bez dowcipu i puenty.

\section{Oksztoń-Grabarz}

Inaczej szakal polski. Przebywa w mrokach. Odznacza się niesłychaną perfidią i hipokryzją. Jesienią ze sfermentowanych liści gruszki wysysa alkohol i pod zgubnym wpływem tego ostatniego niszczy drzewa i inne meble w salonie przyrody. Nie rozmnaża się zupełnie.

\section{Gżegżółka}

Rodzaj królika dzikiego, krwawookiego. Bez przerwy podskakuje, co go naraża na obrażenia cielesne. Rozmnaża się.

\section{Pseudośniofon krótkowłosy}

Do tej chwili: brak jakichkolwiek danych [... $]^{\prime 11}$.

Natomiast w innej rozprawie - Oszczędności zoologiczne Gałczyński zgłasza postulat redukcji zwierząt oraz podaje ich listę, złożoną ze stworów zarówno istniejących jak nieistniejących ${ }^{12}$.

Mitologie dziecięce mają charakter również ludyczny, ale i wśród nich występują indywidua nacechowane psychologią postrzegania i samoświadomości: Bestiarium Borgesa ułożone alfabetycznie zamykają Zwierzęta lustrzane. U Lewisa Carrolla w powieści Po drugiej stronie lustra pojawia się lustrzany potwór Jabberwocky, który ma skrzydła nietoperza, ogon jaszczurki, szyję węża, zębatą paszczę i pazury ptasie, a więc na tle hybryd mitologicznych wyróżnia się najwyżej zwielokrotnieniem cech o zwierzęcej proweniencji ${ }^{13}$. W fantastycznym świecie Macieja Wojtyszki żyją bardziej tajemniczy zwierciadlani Wicewersowie Dzicy.

11 K.I. Gałczyński, Nieznani mieszkańcy naszych borów, [w:] tegoż, Liryka i groteska, Warszawa 1975, s. 267-268.

12 Tamże, s. 262-264.

13 Niemniej być może właśnie nieokreśloność wyglądu wynikająca z nawarstwienia podobieństw do zwierząt istniejących inspirowała polskich tłumaczy, którzy zgłosili tak liczne 
Michał Łukaszewicz w opowiadaniu (dla dorosłych) Wyzwolony odkrył stwora, który powinien zostać objęty ochroną - w czasach malejącej roli literatury i recesji czytelnictwa. Co jednak najciekawsze, to wprawdzie humorystycznie, lecz także dydaktycznie nacechowana metaliterackość, gdyż nowe zwierzę mogłoby objąć patronat nad pisarzami, a nawet zastąpić na Helikonie Euterpe, Erato i Kaliope, choć tymczasem nie stwierdzono żadnej poświęconej mu ody czy choćby apostrofy. Ów stwór ma imię znaczące "Skrybon", a oto jego dość precyzyjna charakterystyka:

Pisze biegnąc [...] Każda jego stopa ma pięć przeciwlegle ustawionych kopyto-palczatek. Dwie małe, dwie średnie i jedną dużą. Ich wzajemne ułożenie tworzy odpowiedni znak, a sposób stawiania nóg - system znaków. Przecinki i kropki stawia ogonem ${ }^{14}$.

Granice i ścieżki ludzkiej wyobraźni kreującej quasi-przyrodnicze byty domagają się jakiejś systematyki fantastycznej. Najbliżej spełnienia tej idei był chyba Borges. Gdyby stworzyć bestiarium kompletne, gromadzące pomysły wszystkich mitologii, fantazji literackich i plastycznych (Salvador Dali miałby tu wkład bodaj największy), to prawdopodobnie wirtualną faunę dałoby się usystematyzować wedle reguł retoryki i poetyki.

Figury per adiectionem - Cerber, Hydra, Amfisbena (wąż o dwóch początkach), Bayamus (trzynogi stwór z noweli Stefana Themersona).

Figury per detractionem - np. Jednorożec (Unicorn), Cyklop (jednooki), Nosnos (który „ma tylko jedno oko, jeden policzek, jedną nogę i pół serca”) ${ }^{15}$.

Figury per immutationem - ta grupa miałaby chyba największą reprezentację, bo skupia wszystkie krzyżówki i kontaminacje, a więc hybrydy, takie jak Minotaur, Centaur, Pegaz, Gryf.

Figury per ordinem - „wąż, który zaczyna się na końcu swojego ogona” $\mathrm{z}$ zoologii fantastycznej Borgesa ${ }^{16}$.

\section{W ogrodzie niezoologicznym Leśmiana}

Zasadniczą odrębność postaci fantastycznych ze światów przedstawionych Leśmiana określić można tak: nie tyle mieszczą się one w kolejnej zoologii fantastycznej, ile stanowią niepodległą republikę ontologii fantastycznej. Na streszczonym tu pstrokatym tle mitologii i jej dwudziestowiecznych aneksów stwory Leśmiana zdecydowanie wyróżniają się zarówno substancjalnie, jak funkcjonalnie. $\mathrm{W}$ mitologiach dominują bowiem bestie siejące zniszczenie,

propozycje nazwania bestii: Dziwolęki (Antoni Marianowicz lub Hanna Baltyn), Żabrolaki (Robert Stiller), Dżabbersmok (Maciej Słomczyński), Dziaberlak (Jolanta Kozak), Żebrolak (Janusz Korwin-Mikke), Dziabrliada (Stanisław Barańczak). Podaję za: Jabberwocky, stroną: https//pl.wikipedia.org-wiki-Jaberwock (dostęp: 30.11 2017).

14 M. Łukaszewicz, Wyzwolony, [w:] tegoż, Dom z zapalonymi świattami, Kraków 1987, s. 53.

15 J.L. Borges, Księga istot zmyślonych, s. 137.

16 Tamże, s. 206-207. 
śmierć, zło; przeważnie są krwiożercze i władcze albo przynajmniej podstępne i oszukańcze. Niewiele znajdziemy pośród nich istot sympatycznych, opisywanych przez litotę i hipocoristicum. Postaci Leśmianowskie wydają się antytezą takich kreacji, reprezentując zamiast grozy i potęgi raczej słabość, kruchość i efemeryczność egzystencji, a nawet kompleks niższości; przede wszystkim rzadko straszą (do wyjątków należy Dusiołek), a jeśli budzą przerażenie, to raczej dlatego, że same boją się i zasługują na współczucie.

$\mathrm{W}$ mitologiach dominuje mimetyzm, a więc fauna podobna jest do rzeczywistej, lecz wynaturzona, poddana hiperbolizacji pewnych cech morfologicznych lub skrzyżowana w hybrydę. Natomiast Leśmian, choć stosuje również opis antropomorficzny lub animalistyczny, przede wszystkim reifikuje abstrakcję ${ }^{17}$. Jego stwory istnieją w perspektywie eks-centryczności i anty-antropocentryzmu, których konsekwencjami są hipotetyczne kreacje odmiennych świadomości u istniejących realnie obiektów natury. Podobną funkcję w poezji Zbigniewa Herberta pełni Kamyk, a w wierszach Wisławy Szymborskiej: śniący stary żółw, tarsjusz czy ziarenko piasku. Leśmianowi chodzi nie tyle o popis fantazji w kreowaniu istnień przez naturę „przeoczonych", ile o alternatywny punkt widzenia rzeczywistości, o przeciwstawienie antropocentrycznym schematom poznania innych stanów świadomości jako „Światów możliwych", otwarcie nowego horyzontu epistemicznego. Stwory Leśmiana są niekiedy hipostazami dylematów ontologii i egzystencji; dlatego warto sięgnąć po kategorię innobytu, którą wprowadził Stanisław Balbus piszący o „światach możliwych” w poezji Wisławy Szymborskiej; choć w tej analogii konieczne będą pewne istotne zastrzeżenia.

Na pewno Leśmianowskie istoty reprezentują jakiś „byt zachwiany w swej pewności ontologicznej"18 - z tym, że w odróżnieniu od realnych obiektów przyrody, które obdarza świadomością autorka Wielkiej liczby, są to formy przyrody fantastyczne. $W$ obydwu przypadkach jednak stanowią alternatywną wizję świata przeciwstawioną antropocentryzmowi, a zatem otwierają zewnętrzne, pozaludzkie perspektywy postrzegania rzeczywistości, założone eksperymentalnie w celu zakwestionowania albo przynajmniej podważenia rutyny poznania naukowego i potocznego. Pisze Stanisław Balbus:

Wszędzie hipotezy takie stawiane są po to, aby powiedzieć coś ważnego o świecie aktualnym, zaistniałym, co pośród urzeczywistnionych i oswojonych faktów pozostaje gołym okiem niewidoczne ${ }^{19}$.

Dalej badacz obszernie uzasadnia uniwersalizm zewnętrznej perspektywy oglądu rzeczywistości:

17 M. Głowiński, Zaświat przedstawiony. Szkice o poezji Bolesława Leśmiana, Warszawa 1981, s. 34, 200.

18 S. Balbus, Świat ze wszystkich stron świata. O Wisławie Szymborskiej, Kraków 1996, s. 135.

19 Tamże. 
Rola „innobytów” polega przede wszystkim na tym, że ich perspektywa może obejmować - i ustanawiać jako jeden ze światów możliwych - całą przestrzeń rzeczywistości ludzkiej i całą ludzką historię ${ }^{20}$.

U Szymborskiej takie egzotyczne spojrzenia na świat mają niewątpliwie motywację poznawczą, nawet jeśli wyczerpują się na krytyce epistemé. W przypadku Leśmiana intencja nie jest już tak oczywista, gdyż dociekania o naturze świata pojawiają się incydentalnie, a zwykle toną $\mathrm{w}$ osobliwie przygodowej fabule. Zanurzenie $\mathrm{w}$ alternatywnej irracjonalnej dziwności wydaje się często ważniejsze niż diagnozowanie świata realnego.

Metodą kreacji Leśmianowskich innobytów jest opis fragmentaryczny, jeśli chodzi o wygląd, gdyż ogranicza się do wymienienia paru cech, niekoniecznie istotnych, ale zawsze uzasadnionych funkcjonalnie a rozproszonych i rzucanych jakby mimochodem przez narratora skupionego głównie na dynamice balladowej akcji.

Przyjrzyjmy się najważniejszym osobnikom, a raczej ich streszczonym rysopisom, które nie mogłyby posłużyć za materiał do portretów pamięciowych rysowanych jako załączniki do listów gończych.

Śnigrobek - ma wygląd niedookreślony: jest „błękitnawo zapatrzony w paproć", a wędrując w dal "się złoci", ale nawet te skąpe i zmienne cechy tracą znaczenie $\mathrm{w}$ rozwijającej się fabule, a rysem istotnym pozostaje tylko to, że egzystuje on gdzieś na niepewnym pograniczu życia i śmierci.

Zmierzchun - nie ma żadnego wyglądu, choć łączy cechy antropomorficzne ze zwierzęcymi; dokonuje gwałtu na śpiącej dziewczynie - może więc być hipostazą pożądania, popędów Erosa i Tanatosa, instynktu z pogranicza miłości i śmierci; a więc i Freudowskiej nieświadomości.

Niewidzialni - są bytami programowo abstrakcyjnymi, tworami duchowymi, ale jednak wyposażonymi namiastkowo w konkret cielesny: mają "dłonie".

Pozorzanie - to twory pochodne od człowieka i przezeń wyśnione, ale zarazem zwrotnie śniące o nim; lecz idealne, nieśmiertelne, przez co bliższe Bogu.

Skrzeble - wydają się wyjątkowe jako zwierzęcopodobne drapieżniki, a konkretnie gryzonie: „kogo gryzą we śnie, ginie ten na jawie”. Sen im wystarcza, ponieważ same istnieją jedynie warunkowo: śnią swe istnienie i „nie żyją nigdy, tylko umierają". Są więc swego rodzaju bytem regresywnym, a ponadto - krzywym lustrem człowieczeństwa, przypominającym, że już począwszy od urodzenia każda chwila przybliża nas do śmierci; a zatem sensem życia musi być jego zanik.

Srebroń - to personifikacja lub animalizacja efektów świetlnych (gwiazd, księżyca, rosy) w walce resztek światła z nadchodzącym mrokiem. Jest energią światła, która udziela blasku otoczeniu, a tym samym staje się w nocy ostatnim azylem istnienia, nawet zastępując Boga. Nie wiadomo, jak sam

20 Tamże, s. 159-160. 
wygląda, gdyż chyba w ogóle wyglądu nie posiada jako byt niesubstancjalny. Jest „,niepoprawnym Istnieniowcem”, co można rozumieć jako czysty wyabstrahowany z materii, bezcielesny akt bycia, przeciwstawiony śmierci i nicości. Zjawisko przyrody, któremu Leśmian nie pozwala zastygnąć w żadnej antropomorfizacji, jak to czyniły dawne mity. Jego portret wyłania się jednak nie tylko z fragmentarycznego opisu, ale również ze stylistyki narracji, $\mathrm{z}$ „międzysłowia”, gdyż układy brzmieniowe, a dokładniej chwyt instrumentacyjny nazwany przez Ferdinanda de Saussure'a ",anagramem brzmieniowym" wykrył w swej interpretacji Srebronia Edward Balcerzan ${ }^{21}$. Trzeba uznać wyjątkowość Srebronia pośród bohaterów innych ballad, gdyż zastosowana metoda wydaje się bliska zarówno późniejszym doświadczeniom poezji konkretnej, jak autotematyzmowi, manifestując zawisłość bohatera od językowej kreacji. Właśnie w tym utworze osiąga najwyższe natężenie relacja, o której pisze Michał Głowiński: „homologia między niezwykłością wysłowienia a niezwykłością zdarzeń i wzajemnej ich motywacji”; język i mowa przenikają do fantastycznej fabuły i droga wyobraźni wiedzie od metafory do mitu ${ }^{22}$.

Łatwo zauważyć, że nie wszystkie imiona "mówiące”, czyli utworzone od pojęć, nazw przedmiotów, zjawisk lub czynności, wydają się adekwatne w świetle skąpych opisów postaci oraz ich przygód. W imieniu Zmierzchuna trudno dopatrzyć się ścisłego związku z jego przestępczą działalnością, a jedynie pora dnia pośrednio nasuwać może dalekie skojarzenia z erotyką i przemocą.

Innobyty Leśmiana przeważnie wiodą żywot samotników; a niektóre, choć występujące w liczbie mnogiej jak Skrzeble czy Pomorzanie, nie tyle żyją w stadach, ile tworzą wspólnotę gatunku - równie wykluczoną lub zmarginalizowaną. Wprawdzie przeżywają osobliwie świat realny, nawiązując z nim kontakt i egzotyczne dialogi, ale wzajemnie się nie znają, żyjąc w światach równoległych tak samo dziwnych, a jednak wobec siebie osobnych; nie tworzą mieszanego królestwa zwierząt w jednym rezerwacie, choć wspólnotę niektórych ustanawia niekiedy dopiero perspektywa kreatora - jak w wierszu Dokoła klombu, przedstawiającym korowód osobnych światów z ich bohaterami, który zamyka cykl Postacie i ujmuje niejako w cudzysłów jednej modalności: wszystkie wykreowane istoty okazują się wytworami marzeń sennych.

Indywidualistą jest również postać pochodząca z tego samego cyklu (ze zbioru Napój cienisty), którą jako najciekawszą obrałem za przedmiot interpretacji.

\section{Znikomek}

W cienistym istnień bezładzie Znikomek błąka się skocznie.

Jedno ma oko błękitne, a drugie - piwne, więc raczej

21 E. Balcerzan, Petno rozwiśleń i udniestrzeń, [w:] tegoż, Oprócz głosu. Szkice krytycznoliterackie, Poznań 1971, s. 29-44.

22 M. Głowiński, Zaświat przedstawiony. Szkice o poezji Bolesława Leśmiana, s. 100-101. 
Nie widzi świata tak samo, lecz każdym okiem - inaczej -

I nie wie, który z tych światów jest rzeczywisty - zaocznie?

Dwie dusze tai w swej piersi: jedna po niebie się włóczy -

Druga - na ziemi marnieje. Dwie naraz kocha dziewczyny:

Ta czarna - snu wieczystego na pamięć barwnie się uczy -

Ta jasna - całun powiewny tka dla umarłej doliny.

Którąż z nich kocha naprawdę? Złe ścieżki! - Głębokie wody! -

Urwiska! - Nawoływania! - I znikąd żadnej pomocy! -

I powikłane od lęku, w mrok pierzchające ogrody! -

A w dłoniach - nadmiar istnienia, a w oczach - okruchy nocy!

I mgła na ustach dziewczyny, rumianych marzeń rozgrzewką A kwiaty wzajem się widzą - a zgony wzajem się tłumią! -

Znikomek spożył kęs nieba i miesza złotą mątewką

Cień własny z cieniem brzóz kilku. A brzozy śnią się i szumią ${ }^{23}$.

Ta stosunkowo krótka ballada, złożona zaledwie z czterech 16-zgłoskowych tetrastychów ze średniówką 8+8, sama wydaje się „znikoma” - jak chciałoby się rzec, wmawiając poecie gest autotematyczny, podobny jak w innych przypadkach przenikania cech świata przedstawionego do tytułów: Ballada bezludna, Ballada dziadowska. Byłaby to zatem przez analogię „Ballada znikoma" - jeśli chodzi zarówno o niewielkie rozmiary tekstu, jak fabułę zminimalizowaną do wyrywkowej charakterystyki postaci, opisu sytuacji i paru zdarzeń. Oto Znikomek błąka się w swym środowisku - zapewne naturalnym, ale od początku mu nieprzyjaznym, podejmując daremne wysiłki poznawcze i erotyczne: postrzega wzrokiem, odczuwa, przeżywa i próbuje kochać. W swych działaniach zarówno epistemicznych jak miłosnych wykazuje niemoc, a jego bezsilne dążenia kontrastują z typową dla Leśmianowskiego świata nadaktywnością przyrodniczej scenerii. Smutny los zmarginalizowanego istnienia, sytuujący go pośród licznych banitów z innych ballad, wydaje się niemą skargą albo jakąś interpelacją do domniemanego Stwórcy, protestem przeciw ontologicznemu wykluczeniu.

A przecież Znikomek jednak istnieje, choć z góry skazany na byt niepełny, o czym programowo uprzedza jego mówiące imię. Nie wiadomo jednak, czego dotyczy zaprogramowany w nim minimalizm. Na czym polega kalectwo lub niespełnienie? Czy na tym, że istnieje w sposób niewidzialny, namiastkowy, czy też nieświadomy lub niepewny? Czy ten stan bycia na marginesie rzeczywistości albo pomiędzy jej sferami sytuuje go na granicy egzystencji, czy może tylko na granicy poznania i samoświadomości? Czy wreszcie chodzi o to, że jego istnienie polega właśnie na stopniowym, lecz nieskończonym zanikaniu, zmierzającym do nieosiągalnej asymptoty absolutnego nieistnienia?

23 B. Leśmian, Poezje zebrane, oprac. A. Madyda, wstęp M. Jakitowicz, Toruń 2000, s. 364. 
Wszystkie te wykładnie imienia wydają się równie prawomocne może z wyjątkiem tej najbanalniejszej, że chodzi po prostu o małe rozmiary stworzonka; jest ono bowiem wszechobecne, choć skazane na wieczne błądzenie niczym Żyd Wieczny Tułacz. Wydaje się jednak przede wszystkim reprezentacją uniwersalnej ludzkiej bojaźliwej niepewności egzystencjalnej i epistemicznej.

By sprawdzić jego tożsamość najpierw poznajmy wygląd, potem czyny i pragnienia tej osobliwej postaci. Zacznijmy zatem od rysopisu.

\section{Granice widzenia i zagranica widzialności}

Naturalnym odruchem czytelnika jest uruchomianie procesu, nazwanego przez Romana Ingardena „konkretyzacją", toteż nie powinno dziwić naiwne dążenie każdego interpretatora, by postać czy szerzej; „aktanta”, portretowanego w balladzie spróbować jakoś „zobaczyć”, czyli dopełnić jego przemilczany wygląd siłą własnej wyobraźni. W tym wypadku jednak w punkcie wyjścia tej procedury dysponujemy danymi wyjątkowo skąpymi, dostarczonymi przez ledwie szczątkowy opis, który zresztą skupia się bardziej na otoczeniu niż samym bohaterze. Z charakterystyki, raczej psychologicznej i behawioralno-funkcjonalnej, dowiadujemy się bowiem zaledwie tyle: Znikomek porusza się "skocznie" (a więc rytmicznie, tanecznie, co może oznaczać także „poetycko”) i ma zdolną do miłości „duszę”. Jeśli chodzi o wygląd zewnętrzny, to prócz jakiegoś narządu służącego do odżywiania oraz przyrządzania pokarmu ma w swym rysopisie jedynie cechę szczególną: różnobarwną parę oczu.

Wymienione cechy wystarczają jednak, by skierować naszą wyobraźnię na tory analogii ze światem zwierzęcym albo zasugerować jakiś antropomorfizm, a te asocjacje aktywizują już pewne automatyzmy w dalszym implikowanym dookreślaniu prawem prostych podobieństw. Skoro Znikomek „skacze”, to musi mieć nogi, jeśli coś zjada, to ma jamę ustną, pysk, ryj, gębę albo paszczę, a żeby mógł coś „mieszać”, powinien być wyposażony w jakiś narząd chwytny: nibynóżki, macki, język lub ogon, wreszcie łapy lub ręce ale w trzeciej strofie czytamy nawet o antropomorficznych „dłoniach".

Poszukujemy natomiast jeszcze atrybutów innych niż ludzkie i zwierzęce, a więc jakichś elementów dystynktywnych w morfologii ciała, które zdecydowanie odróżniają Znikomka od znanych gatunków fauny i form humanoidalnych, także tych z różnych etapów antropogenezy. Szczegółowy rysopis pozostaje jednak w sferze dowolnych domniemań, gdyż jako przemilczany w opowieści stanowiłby nie lada wyzwanie dla imaginacji policyjnego rysownika, podejmującego próbę stworzenia "portretu pamięciowego" ściganego obiektu. Ubogi materiał empiryczny narażony jest zatem z jednej strony na serię łatwych stereoty powych dopowiedzeń, z drugiej na nieograniczoną dowolność suplementacji, swawolę fantazji i "radosną twórczość" - bliską baśni, mitologii lub science fiction. Obie drogi zaprowadzą donikąd, gdyż stwór konkretyzowany tymi metodami utraci swą ontologiczną niepowtarzalność 
i tylko zasili ogromne zasoby istniejących $\mathrm{w}$ kulturze bestiariów o stwora, będącego kolejnym, wprawdzie niedokładnym i niezamierzonym, duplikatem któregoś z dawnych pomysłów.

Dlatego przyjrzyjmy się Leśmianowskiemu opisowi uważniej, by powściągliwie uzupełnić go o cechy w utworze przemilczane. Znając ogólny kierunek i cel fantastycznych kreacji autora Łąki domyślamy się przecież, iż najważniejszy w nich nie musi być wcale wygląd (stąd jego szkicowość), lecz charakterystyka miejsca innobytu w świecie. Groteskowo różnobarwna para oczu zdarza się, nawet pośród ludzi - choć nieczęsto, co wykorzystał Michaił Bułhakow sygnalizując wyjątkowość proweniencji Wolanda:

Prawe oko czarne, lewe nie wiedzieć czemu zielone. Brwi czarne, ale jedna umieszczona wyżej niż druga. Słowem - cudzoziemiec $^{24}$.

Ta rzadka cecha genetycznego zakłócenia pigmentacji tęczówki jednak nie powoduje zaburzeń w postrzeganiu świata przez człowieka. U Znikomka natomiast jest inaczej: oko niebieskie i oko piwne determinują dwoistą percepcję rzeczywistości i ustanawiają jego wyalienowaną tożsamość. Zauważmy jednak od razu, że ten fakt wcale nie jest oczywisty w perspektywie narratora, dysponującego wiedzą ograniczoną przez pozycję zewnętrznego obserwatora, który potrafi wysnuć zaledwie hipotezę psychologiczną:

Jedno oko błękitne, a drugie - piwne, więc r a c z e j

Nie widzi świata tak samo, lecz każdym okiem inaczej.

[podkreśl. - P.M.]

Nadal nie wiadomo jednak, na czym owa różnica widzenia polega: czy oznacza, że Znikomek widzi podwójnie, czyli dwa obrazy nakładają mu się niby w diaporamie, czy też widzi niestereoskopowo (bez ogniskowej), każdym okiem inny fragment otoczenia - jak płastuga czy kameleon, których wzrok jest rozbieżny, a kierunek i pole widzenia niezależne dla każdej gałki ocznej?

W opowieści o życiu Znikomka i poetyckim opisie gatunku jego wygląd jest więc kwestią drugorzędną, a głównym zagadnieniem staje się to, co i w jaki sposób Znikomek widzi. Możemy więc porzucić wysiłki, by go koniecznie „zobaczyć" w jakimś kształcie fizycznym - na rzecz empatycznego wniknięcia w sam punkt i zakres jego widzenia - w perspektywę postrzegania świata, która może okazać się alegorią epistemé i manifestacją pewnego światopoglądu.

To sam Znikomek, z jego zagadką odczuć i przeżyć, staje się przedmiotem dociekań narratora. Stwór usytuowany w jakimś niemożliwym a przynajmniej nieuchwytnym i niewyobrażalnym, zerowym punkcie percepcji całego Wszechświata, punkcie zarazem ruchomym, bo przemieszczającym

24 M. Bułhakow, Mistrz i Małgorzata, przeł. I. Lewandowska i W. Dąbrowski, Warszawa 2001, s. 13-14. 
się skokowo (bo „skocznie”) i stochastycznie niczym ruchy Brauna. Być może to byt podobny do mikroskopijnej cząsteczki lub atomu - niewidzialny, ale na pewno widzący.

\section{Znikomek i świat}

Efemeryczna i zmarginalizowana pozycja Znikomka służy opisowi otaczającej go przestrzeni, którą błądzi, a zatem która w efekcie posłużyć mogłaby do sformułowania jakiejś diagnozy rzeczywistości. Znikomek jest bowiem niepojętego świata wytworem albo jego konsekwencją. Pierwsze słowa ballady to okoliczniki miejsca, a więc elementy opisu lokalizującego, który właśnie scenerię eksponuje na pierwszym planie: „W cienistym istnień bezładzie".

Mrok i chaos, w którym bohater nie potrafi się zadomowić i którego nie potrafi zrozumieć, skazuje go na sprzeczne hipotezy, między którymi waha się jego percepcja. Dusza Znikomka przeżywa odwieczny dylemat poznawczy i bliskie psychomachii rozdarcie na dwie przeciwne tęsknoty duszy i ciała: do nieba albo do ziemi. Ścierają się opozycyjne stanowiska ontologiczne, przywołując odwieczną antynomię idealizmu i materializmu. Byłaby to dość czytelna parabola, gdyby nie została skomplikowana inną antynomią. Rozterka pragnień nakłada się bowiem na dwie koncepcje miłości, reprezentowane przez dwie dziewczyny. Nie chodzi tu jednak o erotyzm, lecz o kolejny dylemat epistemologiczny: która miłość jest prawdziwa, skoro już trzeba wybierać tylko jedną, z koniecznością wykluczenia drugiej. Tymczasem jednak charakterystyka obu elementów tej alternatywy rozłącznej (dysjunkcji) nie jest wcale tak oczywista, jak może sugerować manichejsko-moralitetowe skontrastowanie brunetki z blondynką:

Ta czarna - snu wieczystego na pamięć barwnie się uczy,

Ta jasna - całun powiewny tka dla umarłej doliny.

Są to chyba najbardziej enigmatyczne wersy w całym utworze. „Czarna” należy do postrzegania barwnego rzeczywistości, ale zmusza zarazem do zerwania ze światem dla wieczności i wyboru "zaświata”. "Jasna" natomiast - nie można stwierdzić, że czyni na odwrót, a wolno przypuścić, że postępuje podobnie jak tamta, ale inną drogą, bo "całun powiewny" to tylko odmienna forma wieczności, która jakoś zasnuwa rzeczywistość materialną. Na czym więc polega przeciwieństwo tych przedsięwzięć i narzucony przez nie Znikomkowi dylemat wyboru? Może na przeciwstawieniu widzialności i niewidzialności? Dla pierwszej dziewczyny aksjomatem jest widzialna powierzchnia barwnego świata fizycznego, gdyż ten skrywa wieczność niby niewidoczną podszewkę. Dla drugiej natomiast absolutem jest sama idea wieczności. Arystotelizm versus platonizm? Sądy aposterioryczne contra aprioryczne? Empiria przeciwstawiona wierze? 
Niepewność, nieoznaczoność, chaos - to sens ostatniej strofy, niejako nawiązującej do punktu wyjścia; zakończenie otwarte, typowe dla Leśmianowskich fabuł balladowych, w których finale u kresu dążeń bohatera czyha z góry przygotowana i przeczuwana klęska. Kwestia, gdzie się znajduje rzeczywistość prawdziwa: czy prawda leży po stronie realizmu, czy też idealizmu ontologicznego, pozostaje nierozstrzygnięta i okazuje się nierozstrzygalna. Z jednej strony „w dłoniach nadmiar istnienia” stanowi empiryczny dowód na istnienie świata materialnego; z drugiej - „okruchy nocy” sprawiają, że wzrok napotyka na tajemnicze granice postrzegania sensorycznego i tonie w bezmiarze możliwości snu.

Dezorientacja Znikomka wydaje się alegorią rozterek filozofów. W końcu zatraca on własną odrębność od świata i gubi świadomość opozycji między podmiotem a przedmiotem poznania, gdyż miesza "Cień własny z cieniem brzóz kilku” - jakby pragnąc integracji ze światem. Co ważne jednak, tłem jego klęski osamotnienia a zarazem przejawem obojętności wobec niej otoczenia jest bezkolizyjna odwieczna komunikacja między bytami natury:

A kwiaty wzajem się widzą - a zgony wzajem się tłumią! -

[...] A brzozy śnią się i szumią.

Dramat w życiu doskonale skomunikowanych i wzajemnie rozumiejących się roślin pozostaje przeoczonym albo zignorowanym przez przyrodę epizodem. Ofiara w skali Wszechświata: przemian pór roku, dnia i nocy, ruchu planet pozostaje właśnie nieistotnym „Znikomkiem”. Nie należąc ani do świata roślin, ani królestwa zwierząt, ani sfery ludzkiej; nie mieszcząc się ani po stronie natury, ani kultury, żyje na pograniczu ich wszystkich jak wielokrotny banita. Jego status ontyczny pozostaje wątpliwy; być może jest zaledwie niespełnionym projektem Stwórcy, wynalazkiem teoretycznie możliwym, dziełem niepodległej wyobraźni albo rywalizującym z ziemską rzeczywistością poetyckim postulatem. W świecie przedstawionym na pewno egzystuje na marginesie istnienia, który jednak może skupiać największe tajemnice całego Bytu.

\section{B I B L I O G R A F I A}

Balbus S., Świat ze wszystkich stron świata. O Wisławie Szymborskiej, Kraków 1996.

Balcerzan E., Petno rozwiśleń i udniestrzeń, [w:] E. Balcerzan, Oprócz głosu. Szkice krytycznoliterackie, Poznań 1971, s. 29-44.

Borges J.L., Księga istot zmyślonych, przeł. Z. Chądzyńska, Warszawa 2000.

Bułhakow M., Mistrz i Małgorzata, przeł. I. Lewandowska i W. Dąbrowski, Warszawa 2001. Gałczyński K.I, Nieznani mieszkańcy naszych borów, [w:] K.I. Gałczyński, Liryka i groteska, Warszawa 1975, s. 267-268.

Głowiński M., Zaświat przedstawiony. Szkice o poezji Bolesława Leśmiana, Warszawa 1981. Lem S., Jak ocalał świat, [w:] S. Lem, Opowiadania wybrane, Kraków 1975, s. 121-125. 
Lem S., Ratujmy kosmos (List otwarty Ijlona Tichego), [w:] S. Lem, Dzienniki gwiazdowe, Warszawa 1971, s. 413-430.

Leśmian B., Poezje zebrane, oprac. A. Madyda, wstęp M. Jakitowicz, Torun 2000.

Łukaszewicz M., Wyzwolony, [w:] M. Łukaszewicz, Dom z zapalonymi światłami, Kraków 1987.

Bomba $i$ inni. Postacie, https//pl.wikipedia.org/wiki/Bromba_i_inni\#Postacie. Jabberwocky, https//pl.wikipedia.org-wiki-Jaberwock. Jedi, https//pl.wikipedia.org/wiki/Jed.

\section{STR ESZCZEN IE}

Artykuł jest próbą usytuowania świata osobliwych stworów kreowanych w balladach Bolesława Leśmiana wobec innych bestiariuszy wywiedzionych z mitologii oraz literackich kreacji w zakresie: science fiction, baśni i groteski, twórczości dla dzieci i kultury popularnej, m.in. Jorge Luisa Borgesa, Stanisława Lema, Konstantego Ildefonsa Gałczyńskiego, Macieja Wojtyszki. Na tym tle odrębność wyobraźni Leśmiana skłania do nazwania jej ontologią fantastyczną i odniesienia do kategorii „innobytu”. Leśmian kreuje swe postaci w perspektywie anty-antropocentrycznej jako istnienia alternatywne. Ich wyglądy pozostają niedookreślone, gdyż szczątkowe charakterystyki rozpraszone w narracji skupiają się przede wszystkim na ich marginalizowanej wobec świata realnego egzystencji. Przegląd ważniejszych Leśmianowskich stworów zamyka szczegółowa interpretacja ballady Znikomek ze zbioru Napój cienisty.

\section{Słowa kluczowe}

Leśmian Bolesław, poezja polska XX wieku, bestiariusz, mitologia, zoologia fantastyczna, fantastyka naukowa, literatura współczesna, tradycja kultury

\section{SUMMARY}

\section{Znikomek among other-beings. Analysis of the anatomy of Leśmian's imagination}

The article is an attempt to situate the world of peculiar creatures created in the ballads of Bolesław Leśmian with other bestiaries drawn from mythology and literary creations in the field of science fiction, fairy tales and grotesque, creativity for children and popular culture, by, for instance, Jorge Luis Borges, Stanisław Lem, Konstanty Ildefons Gałczyński, Maciej Wojtyszko. Against this background, the distinctiveness of Leśmian's imagination makes us call it a fantastic ontology and references to the category of "other-beings". Leśmian creates his characters in an anti-anthropocentric perspective as an alternative existence. Their appearance remains undetermined as the residual characteristics dispersed in the narrative focus primarily on their existence marginalized with regard to the real world. An 
overviewof the most important Leśmian creatures closes with a detailed interpretation of the ballad Znikomek from the collection Napój cienisty (Shadowy Drink).

\section{Keywords}

Leśmian Bolesław, Polish poetry in the 21st century, bestiary, mythology, fantastic zoology, science fiction, contemporary literature, tradition of culture 